\title{
The role of social capital in the victimization risk against property: evidence from Brazil *
}

\author{
Gustavo Carvalho Moreira ** \\ Ana Lucia Kassouf **** $^{*}$ \\ Marcelo Justus
}

\begin{abstract}
The economic model of crime presupposes that individuals evaluate the decision to commit a crime rationally. A more inclusive version of this model would include social capital as a factor influencing criminal activity. The amount of social capital that exists within a group can be used to explain criminal behavior, and an increase in the level of social capital can be a factor capable of preventing crime. This study tests the hypothesis that increasing the level of social capital reduces the risk of victimization against property. Results from variations of an IV-Probit model were used to evaluate data from Latin American Public Opinion Project surveys conducted in Brazil. These results suggest that a higher level of social capital among individuals increases the likelihood that they will cooperate for mutual benefit, such as combating crime.
\end{abstract}

Keywords: Interpersonal trust; Social cohesion; Economy of crime.

\section{Resumo}

O papel do capital social no risco de vitimização contra a propriedade: evidências para o Brasil

O modelo econômico do crime pressupõe que indivíduos racionalmente decidem participar de uma atividade criminosa. Uma versão mais ampla desse modelo também inclui o capital social como um dos fatores que afetam a entrada na atividade ilegal. Isso porque a quantidade de capital social existente em determinado grupo de indivíduos pode também ser utilizada para explicar o comportamento criminoso, uma vez que um aumento no nível de capital social é um fator capaz de prevenir a criminalidade. Este estudo testa a hipótese de que um maior nível de capital social reduz o risco de vitimização contra a propriedade. Variações de um modelo IV-Probit foram utilizados para verificar o fenômeno a partir de dados da Latin American Public Opinion Project realizada no Brasil. Os resultados sugerem que um maior nível de capital social entre indivíduos aumenta a probabilidade de cooperarem para um benefício mútuo, como o combate à criminalidade.

Palavras-chave: Confiança interpessoal; Coesão social; Economia do crime.

JEL C35, D01, K14.

\section{Introduction}

Crime implies costs related to the erosion of social well-being due to fear and insecurity, an increase in public and private security spending, and a reduction in the stock of human capital. In regard to this social problem, Brazil stands out. The country has the largest

\footnotetext{
* Article received on June 26, 2017 and approved on December 18, 2017.

** Professor in the Department of Economics at the University of São João del Rei (UFSJ), MG, Brazil. E-mail: gustavocmoreira@ufsj.edu.br.

${ }^{* * *}$ Professor in the Department of Economics and Rural Sociology at Luiz de Queiroz College of Agriculture (Esalq), Piracicaba, SP, Brazil. E-mail: anakassouf@usp.br.

${ }^{* * * * *}$ Professor in the Institute of Economics at the University of Campinas (Unicamp. IE), Campinas, SP, Brazil. E-mail: mjustus@unicamp.br.
} 
absolute number of homicides in the world and the $12^{\text {th }}$ highest homicide rate per 100,000 inhabitants (World Health Organization - WHO, 2014). These dismal statistics are not improving: between 2000 and 2012, the global homicide rate decreased 16 percent while Brazil's rate increased 8.6 percent (WHO, 2014).

Given the importance of crime on any society's well-being, many studies have been developed by those involved in the multidisciplinary field of criminology. Becker's seminal work "Crime and Punishment: An Economic Approach" (1968) details the causes of criminal behavior from an economics perspective. According to the author, the decision to participate in criminal activity is based on the agent's economic rationality while evaluating the benefits against the costs of the activity. The economic benefits of illegal activity are associated with its monetary return when compared to the return from licit activities. The costs, in turn, are associated with the probability of being arrested and the severity of the punishment. Social capital is also a factor influencing criminal activity, and merits inclusion in the discussion on criminal motivation, especially the cost of criminal behavior and as an implicit factor affecting the risk of victimization (Lederman; Loayza; Menendez, 2002).

The concept of social capital has been applied in several fields of social sciences, such as economics, administration, and public policy (Quddus et al., 2000). Originally, the term was used when evaluating the importance of social relationships that instill in individuals the notion of collective responsibility (Jacobs, 1961). In a more modern definition proposed by Norris (1996), social capital represents "dense networks of norms and social trust which enable participants to cooperate in the pursuit of shared objectives." Another explanation is provided by Putnam (1993), in which social capital is developed through social interaction in communal organizations, such as networks, thereby creating a set of norms and interpersonal trust to facilitate actions and cooperation for mutual benefit.

Because it is a broad concept, the inclusion of social capital in an empirical analysis is performed through proxies. Akçomak and Weel (2012) argue that these proxies are related to the individual's participation in social organizations, such as churches, unions, nongovernmental organizations or charities, and the level of trust people have in each other. Despite multiple definitions, the level of interpersonal trust is considered one of the most important dimensions of social capital (Fukuyama, 1999; Zak; Knack, 2001, Uslaner, 2002, Beugelsdijk, 2006, Blanco; Ruiz, 2013).

In the economic literature, studies have highlighted the importance of social capital to increase investments and productive efficiency (Dearmon; Grier, 2009), to increase the accumulation of physical capital (Dearmon; Grier, 2011) and human capital (Papagapitos; Riley, 2009; Dearmon; Grier, 2011), and to reduce income inequality (Knack; Keefer, 1997; Zak; Knack, 2001; Knack; Zak, 2002; Bergh; Bjørnskov, 2014).

Applying the social capital concept to the economic theory of crime and considering the criminal's perspective, the level of social capital (i.e., the level of interpersonal trust) in any group should influence the decision to commit a crime because the criminal act eminently 
involves a moral dilemma: to commit a socially reprehensible act or not. The higher the level of social capital in the criminal's society, the greater the disappointment when the society's members become aware that one member has committed a crime and the greater the chance that the criminal will suffer feelings of guilt associated with unethical behavior. In this way, a higher level of social capital within a society would increase costs inherent in a member's commission of a crime. If the benefits from the criminal activity exceed not only the costs in terms of institutional punishment and lost wages, but also the costs arising from societal disapproval and ethical consternation, then the potential criminal's moral threshold will have been crossed and the crime will be committed.

From the perspective of the victim, Putnam (1993) and Dilulio (1996) point out that a higher level of social capital makes it more likely that a society's members will cooperate for their mutual benefit and provide the efficacy of the collective. This could generate mechanisms of social control to fight crime, such as the hiring of private security guards and monitoring the neighborhood. Bursick and Grasmick (1993) also argue that societies with a higher level of social capital inhibit victimization because they are more likely to obtain public services, such as those offered by the police.

According to Bursick and Grasmick (1993), social capital must be an important consideration when trying to lower crime rates. A practical example of this can be found in the Programa Desarollo, Seguridad y Paz (Desepaz), a public policy implemented in Cali, Colombia. Desepaz seeks to increase social capital by encouraging civic participation, strengthening public institutions, and taking action to reduce social conflict. Cuesta et al. (2007) found that the resulting increase in social capital reduced violence and crime in the city.

A number of empirical studies have tested the relationship between social capital and crime. In the international literature, one can highlight studies by Akçomak and Weel (2012), Cuesta and Alda (2012), Blanco and Ruiz (2013) and Corbacho et al. (2014). In the Brazilian literature, the only empirical analysis that considers the connection between social capital and crime can be found in Peixoto et al. (2012). Their study used the same proxy employed in our study (interpersonal trust) to empirically control the effect of social capital on the risk of victimization in the city of São Paulo.

Our study's main objective is to expand the investigation of social capital's effect on the risk of being victimized to the whole of Brazil. A proxy variable, degree of interpersonal trust, is used to represent the level of social capital that exists within a society. The hypothesis is that increased interpersonal trust reduces the risk of victimization in two ways: reducing the benefits from crime and increasing the costs of crime.

This study is divided into five more sections. The empirical model's theoretical framework is briefly presented in Section 2. The data source and a summary of applied econometric procedures are detailed in Section 3. Sections 4 and 5 give preliminary analyzes and empirical results, respectively. Section 6 contains concluding remarks. 


\section{Theoretical framework}

This section contains a discussion of the theoretical underpinnings for this study's empirical model. The theoretical models are designed to predict the influence of social capital on criminal behavior and the possibilities of victimization. From the criminal perspective, the basis for our empirical model is outlined in the theoretical model designed by Lederman, Loayza and Menendez (2002) dealing with the influence of social capital on a criminal's decision to practice an illegal activity. From the victim's perspective, the basis for our empirical model is derived from the model designed by Cohen, Kluegel and Land (1981)

Following Becker (1968), the theoretical model constructed by Lederman, Loayza and Menendez (2002) (LLM model) presupposes that individuals' rationally decide to participate in illicit activity. An individual will decide to commit a crime if the activity's benefits outweigh its costs.

As an extrapolation of the LLM theoretical model, consider a society composed of three individuals $(i, j$ and $z)$. The net benefit $(b l)$ of agent $i$ committing a crime against $j$ depends on the crime's payoff matrix $\left(l_{j}-w_{i}+u\left(\Delta s k_{i}^{e}\right)\right)$. This, in turn, is affected by the opportunity cost of the crime, which is obtained by subtracting earnings from legal activities $(w)$ from the value gained from the criminal activity $(l)$. In addition, the model assumes that an expected change in the social capital of individual $i\left(\Delta s k_{i}^{e}\right)$ affects the net benefit of criminal activity by changing the individual's utility function $(u)$.

Agent $i$ will commit the crime against $j$ if the net benefit $\left(b l_{i j}\right)$ is greater than the individual's moral threshold $\left(M^{*}\right)$, that is, if

$$
b l_{i j}=l_{j}-w_{i}+u\left(\Delta s k_{i}^{e}\right) \geq M^{*}
$$

The wages from the legal activities of agent $i$ are a function of their capital stock ( $k$, which includes human capital) and their social capital (sk) given by

$$
w_{i}=w\left(k_{i}, s k_{i}\right)
$$

where $s k_{i}$, described in Eq. 2, depends on the relations between individual $i$ and other members of society.

In this simplified model, social capital depends on two factors. The first is the social distance $(d)$ between agent $i$ and agents $j$ and $z$. The other is the degree of trust between agents $(r)$ :

$$
s k_{i}=g_{i j}\left(d_{i j}, r_{i j}\right)+g_{i z}\left(d_{i z}, r_{i z}\right)
$$

For simplicity, Eq. 3 is considered additive, such that total social capital is not greater than the sum of the parts. The distance between individuals $(d)$ depends on exogenous factors, such as communication costs (CC), which depend on geographic, cultural and technological factors, among others.

The value of the reward agent $i$ will receive for committing the crime against $j\left(l_{j}\right)$ corresponds to a portion of the income of $j$, that is, 
The role of social capital in the victimization risk against property: evidence from Brazil

$$
l_{j}=\alpha w_{j}=\alpha\left[w\left(k_{j}, s k_{j}\right)\right] ; 0<\alpha<1
$$

Substituting Eqs. 2 and 4 in Eq. 1 follows that

$$
\begin{gathered}
b l_{i j}=\alpha\left\{w\left[k_{j}, g_{j i}\left(d_{j i}, r_{j i}\right)+g_{j z}\left(d_{j z}, r_{j z}\right)\right]\right\} \\
-w\left\{k_{i},\left[g_{i j}\left(d_{i j}, r_{i j}\right)\right]\right\}+u\left(\Delta r_{i j}^{e}\right)+u\left(\Delta r_{i z}^{e}\right)
\end{gathered}
$$

It is also be assumed that capital stock $(k)$ and social distance $(d)$ are fixed. Again, by evaluating the case of individual $i$ committing a crime against $j$, changes in the confidence level of $j$ relative to $i$ would affect the net benefit of committing the crime. This can be seen in Eq. 6, where $\Delta b l_{i j}$ is the total derivative of $b l_{i j}$ from Eq. 5. It is assumed that

$$
\Delta b l_{i j}=\alpha\left(\frac{\partial w_{j}}{\partial r_{i j}} \Delta r_{i j}+\frac{\partial w_{j}}{\partial r_{j z}} \Delta r_{j z}\right)-\left(\frac{\partial w_{i}}{\partial r_{i j}} \Delta r_{i j}+\frac{\partial w_{i}}{\partial r_{i z}} \Delta r_{i z}\right)+\frac{\partial u}{\partial r_{i j}^{e}} \Delta r_{i j}^{e}+\frac{\partial u}{\partial r_{i z}^{e}} \Delta r_{i z}^{e} \text { (6) }
$$

In this scenario we can also consider two different cases. The first relates to the increase in social capital of the society as a whole and the second to the increase in the social capital of the specific group containing potential criminal $i$ and potential victim $j$ (excluding agent $z$ ).

Given that social distance is constant, the increase in social capital is equivalent to the increase in the degree of trust between individuals $(r)$. Thus, in the case of an increase in the social capital of the group as a whole

$$
\Delta r_{i j}=\Delta r_{i z}=\Delta r_{j z}>0
$$

When we replace values greater than zero for $\Delta r_{i j}, \Delta r_{i z}$ and $\Delta r_{j z}$ in Eq. 6 and knowing that $0<\alpha<1$, we can verify that the result will be less than zero for $\Delta b l_{i j}$. In other words, the increase in the whole society's social capital has a negative effect on the net benefit to the agent committing the crime. In the case of an increase in the social capital of the specific group containing potential criminal $i$ and the potential victim $j$

$$
\Delta r_{i j}>0 ; \Delta r_{i z}=\Delta r_{j z}=0
$$

By replacing $\Delta r_{i j}>0$ and $\Delta r_{i z}=\Delta r_{j z}=0$ in Eq. 6 and with $0<\alpha<1$, the result will also be less than zero for $\Delta b l_{i j}$. Through application of the LLM model, it is expected that higher levels of trust both across society and between groups have a negative effect on the net benefit of committing the crime.

Social capital also affects victim behavior. Madalozzo and Furtado (2011) point out that analyzing the relationship between social capital and victim behavior is complex, since there is no consolidating theory capable of substantiating the behavior of the victim to provide a basis for empirical analysis. A theory that offers a basis for empirical analysis of the relationship between social capital and victim behavior was proposed by Cohen, Kluegel and Land (1981) which composes what are known as life-style theoretical models, which are referred to in this paper as the CKL model ${ }^{1}$. According to CKL theory, the risk of victimization is determined by five main factors: exposure, proximity, capacity to secure protection, victim attractiveness, and the nature of the crime. Exposure relates to the potential victim's visibility

(1) For more victimization theories, see Seigel (2006). 
and the visibility of that individual's material goods at any time and place. Proximity, in turn, concerns the individual's distance from areas where violent behavior is more prevalent and that are historically characterized by criminal activities. The capacity to secure protection depends on the effectiveness of actions taken by potential victims to protect themselves from criminal activities (hiring security, installing cameras and safety equipment). A potential victim's attractiveness refers to the apparent physical ability of the victim to resist criminal attack. Finally, the nature of the crime is defined by the type of crime to be committed by the potential offender, which influences the victim's level of risk.

As stressed by Justus and Kassouf (2013), the theory proposed by Cohen, Kluegel and Land (1981) is very broad, and it is difficult to precisely define or determine the influence of theory's variables; however, it is not hard to accept the notion that social capital affects the variables' influences. For example, if the individual feels secure and confident in their community, they will be more likely to explore the neighborhood and use and display items of value. Being rational, a potential victim that feels secure would be expected to have higher levels of confidence in the places and societies in which they feel less likely to be at risk (Justus; Kassouf, 2008).

\section{Methodology}

\subsection{Data}

The majority of this study's data sources are Latin American Public Opinion Project LAPOP surveys conducted by Vanderbilt University. Data for the variables inequality and homicide were obtained from data compiled by Ipeadata. The Lapop surveys have been conducted bi-annually since 2004 in 26 Latin American, Central and North America countries. The first of these surveys carried out in Brazil was in 2006, and the last edition of Brazilian survey results was published in 2014. The main objective of the research is to collect public opinion on issues involving politics, economics, democracy, and civil participation. The survey uses a representative sample of the adult population of eligible voters who are generally over 16 years of age. Only individuals living in "normal" society are able to participate, which excludes people living in boarding schools, hospitals, police academies, military barracks and prisons. The observation unit is the individual, preferably a reference person in the household being interviewed. The sampling method involves stratification determined by the size of municipalities, urban and rural areas, and regions.

For most variables, our study uses Lapop data from surveys conducted in 2010, 2012 and 2014. These data were then organized into sets of pooled data. The surveys from 2006 and 2008 were not used because the data from those surveys were not separated into categories that distinguished victimization of property from victimization of persons.

\subsection{Empirical strategy}

Table 1 names the variables used in the study's empirical victimization model, provides a definition of each variable, and gives a summary of statistics linked with each variable. 
Table 1

The variables used in all variants of the empirical criminal victimization model, their definitions, and their calculated means, standard deviations (s.d.) and expected signals (e.s.).

\begin{tabular}{|c|c|c|c|c|}
\hline \multicolumn{2}{|r|}{ Definition } & \multirow{2}{*}{ Mean } & \multirow{2}{*}{ s.d. } & \multirow[t]{2}{*}{ e.s. } \\
\hline Victim & $\begin{array}{l}1 \text { if the individual was victimized }{ }^{(1)} \text { in the } 12 \text { months before the } \\
\text { research, and } 0 \text { otherwise. }\end{array}$ & & & \\
\hline $\begin{array}{l}\text { Social } \\
\text { capital }\end{array}$ & $\begin{array}{l}1 \text { if the individual considers people who live in their community very } \\
\text { trustworthy or somewhat trustworthy, and } 0 \text { not very trustworthy and } \\
\text { untrustworthy }\end{array}$ & 0.58 & 0.49 & - \\
\hline Work & 1 if the individual works or studies, and 0 otherwise & 0.72 & 0.44 & + \\
\hline Man & 1 if the individual is a man, and 0 otherwise & 0.50 & 0.50 & - \\
\hline Urban & 1 if the individual lives in an urban area, and 0 otherwise & 0.86 & 0.34 & + \\
\hline \multirow{5}{*}{ Classpop } & $\begin{array}{l}1 \text { if the individual lives in a city with less than } 25 \text { thousand } \\
\text { inhabitants }\end{array}$ & 0.08 & 0.26 & - \\
\hline & $\begin{array}{l}2 \text { if the individual lives in a city with between } 25 \text { and } 50 \text { thousand } \\
\text { inhabitants }\end{array}$ & 0.24 & 0.43 & - \\
\hline & $\begin{array}{l}3 \text { if the individual lives in a city with between } 50 \text { and } 200 \text { thousand } \\
\text { inhabitants }\end{array}$ & 0.22 & 0.41 & - \\
\hline & $\begin{array}{l}4 \text { if the individual lives in a city with between } 200 \text { and } 500 \text { thousand } \\
\text { inhabitants }\end{array}$ & 0.20 & 0.40 & - \\
\hline & $\begin{array}{l}5 \text { if the individual lives in a city with more than } 500 \text { thousand } \\
\text { inhabitants }\end{array}$ & 0.26 & 0.44 & Base \\
\hline \multirow{4}{*}{ Age } & 1 if the individual is $16-25$ years old & 0.23 & 0.42 & + \\
\hline & 2 if the individual is $26-35$ years old & 0.25 & 0.43 & + \\
\hline & 3 if the individual is $36-45$ years old & 0.21 & 0.40 & + \\
\hline & 4 if the individual is over 46 years old & 0.31 & 0.46 & Base \\
\hline Schooling & Years of schooling & 8.40 & 3.90 & - \\
\hline \multirow{3}{*}{ Income } & $\begin{array}{l}\text { Class } A-1 \text { if the monthly per capita income is greater than } R \$ \\
1,041.00 \text {, and } 0 \text { otherwise }\end{array}$ & 0.28 & 0.45 & Base \\
\hline & $\begin{array}{l}\text { Class } B-1 \text { if the monthly per capita income is between } R \$ 411,00 \\
\text { and } R \$ 1.040,00 \text {, and } 0 \text { otherwise }\end{array}$ & 0.26 & 0.43 & $?$ \\
\hline & $\begin{array}{l}\text { Class } C-1 \text { if the monthly per capita income is smaller than } R \$ \\
410,00 \text {, and } 0 \text { otherwise }\end{array}$ & 0.46 & 0.49 & $?$ \\
\hline Inequality & $\begin{array}{l}\text { Population ratio of income held by the richest } 20 \% \text { compared to the } \\
\text { poorest } 20 \% \text { of each Federation Unit }\end{array}$ & 0.55 & 0.13 & + \\
\hline Homicide & Homicide rate per 100,000 inhabitants for the Federation Unit & 26.9 & 12.8 & + \\
\hline \multirow{4}{*}{ Gangs } & $\begin{array}{l}\text { The individual's perception regarding the presence of gangs in the } \\
\text { neighborhood: } \\
1 \text { if not at all affected }\end{array}$ & 0.29 & 0.45 & Base \\
\hline & 2 if slightly affected & 0.36 & 0.48 & - \\
\hline & 3 if reasonably affected & 0.16 & 0.37 & - \\
\hline & 4 if greatly affected & 0.19 & 0.39 & - \\
\hline Year & Year dummies & & & \\
\hline State & Federation Unit dummies & & & \\
\hline
\end{tabular}

Note: (1) Unarmed robbery with and without physical threat; armed robbery; burglary of home and extortion. Data obtained from the LAPOP survey databases (2010, 2012 and 2014). The variables inequality and homicide were obtained from data compiled by Ipeadata for the same years as the Lapop data employed. 
The dependent variable victim has a binary characteristic; therefore, a probit model based on Cameron and Trivedi (2005, p.470) is defined as

$$
\text { victim }_{i t}=\beta^{\prime} \text { social capital }_{i t}+\theta^{\prime} \gamma_{i t}+\varepsilon_{i t}
$$

where victim $_{i t}$ assumes a value of 1 if individual $i$ has suffered a crime against property in the twelve months of survey year $t$, and 0 otherwise; $\gamma_{i t}$ is the vector of characteristics that influence the risk of victimization; $\varepsilon_{i t}$ is the random error term normally distributed, and $\theta$ and $\beta$ are parameters to be estimated.

The explanatory variable of interest, social capital ${ }_{i t}$, was constructed from answers to the following question from the survey:

And speaking of the people from around your community, would you say that people in your community are very trustworthy, somewhat trustworthy, not very trustworthy or untrustworthy...? ${ }^{2}$

The answer to this question was categorical, assuming value 1, if the individual answered "Very trustworthy"; 2, if "Somewhat trustworthy"; 3, if "Not very trustworthy"; and 4, if "untrustworthy

To facilitate the interpretation of the social capital variable, the categories were

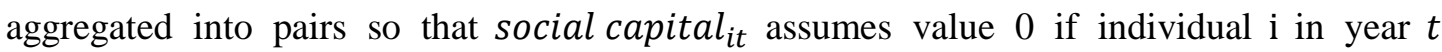
answered "not very trustworthy" or "untrustworthy" and 1 if the response was "very trustworthy" or "somewhat trustworthy."

It is noteworthy that it is expected that $\beta<0$ (i.e., that social capital reduces the risk of victimization). This is the hypothesis tested in this study.

The victimization risk conditional on the values of the explanatory variables contained in $\gamma_{i}$ is given by the following equation:

$$
\operatorname{Pr}(\text { victim }=1)=F\left(\text { social }_{\text {capital }} ; \gamma_{i t}\right)
$$

where $F$ is a cumulative normal distribution function described by

$$
F(z)=\int_{-\infty}^{z} \delta(z) d z
$$

and $\delta(z)$ is the normal standardized density function described by $\delta(z)=(2 \pi)^{-0.5} e^{\left(-\frac{z^{2}}{2}\right)}$.

The marginal effects for the probit model are given by

$$
\frac{\partial \operatorname{Pr}\left[y_{i}=1\right]}{\partial \gamma_{i t} \partial \text { social capital }_{i t}}=F^{\prime}\left(\text { social }_{\text {capital }}^{\prime} \beta ; \gamma_{i t}^{\prime} \theta\right) \theta_{t}
$$

where $F^{\prime}(\mathrm{z})=\frac{\partial \delta(z)}{\partial z}$.

(2) Community refers to the neighborhood in which the individual interviewed lives. 
The role of social capital in the victimization risk against property: evidence from Brazil

In order to avoid bias caused by the presence of unobservable characteristics by the model, the error term will be estimated by neighborhood clusters. Application of the cluster allows observations from individuals belonging to the same neighborhood to be treated as dependents, making it possible to control unobservable variations within each neighborhood and biases caused by omitted variables. This involves, for example, controlling neighborhood characteristics related to income and social inequality, presence of policing, and probability of punishment, which tend to be the same for individuals living in the same neighborhood ${ }^{3}$.

The selection of explanatory variables (Table 1) was conditioned by the LLM and CKL models presented in the previous section and, above all, in previous empirical studies, more specifically those conducted by Scorzafave et al. (2011), Gomes and Paz, (2008), Madalozzo and Furtado (2011), Justus and Kassouf (2013).

The works variable represents a proxy for the exposure to public spaces. If the individual works or studies outside the home, a positive relationship with the risk of victimization is expected. This effect was observed empirically by Justus \& Kassouf (2013).

The variable man represents the gender of the individual interviewed. Women are expected to be more likely to be victimized, since, according to the CKL theory, the apparent physical ability of the victim to resist a criminal attack influences the risk of victimization.

Demographic characteristics were controlled by the urban and classpop variables. The urban variable indicates if the individual resides in an urban or rural environment. This inclusion is motivated by the fact that the distinct dynamicity in urban areas implies a greater occurrence of crime (Wisheit et al., 1994; Muhammad, 2002); although, crime is growing at higher rates in rural rather than urban areas (Rand; Catalano, 2007, Scorzafave et al., 2015, Justus et al., 2016). The classpop variable indicates the number of inhabitants in the interviewee's city and is separated into four sub-groups. A positive relationship is expected between this variable and the risk of victimization given that greater population density increases the risk of the individual living within a potentially violent area. Both the urban and classpop variables capture the distance between individuals $(d)$ as determined by the LLM model and specified in Eq. 3 of Section 2.

It is also expected that the age variable, subdivided into four sub-groups, is negatively correlated with risk of victimization, since younger individuals are more exposed to the risk of victimization than older individuals (Cuesta; Alda, 2012; Justus; Kassouf, 2013; Scorzafave et al., 2015).

With regard to the schooling and income variables, it is expected that the more educated and higher income individuals in Brazil will appear to be higher value targets when exposed in many public spaces. However, individuals with higher incomes also have more financial resources that can be directed toward insuring their own security, which would imply a

(3) For an explanation about clustering effects on the estimates, see Cameron and Miller (2015). 
reduction in the risk of victimization (Justus; Kassouf, 2013). Thus, the effect of the income variable cannot be anticipated.

Three environmental factors capable of influencing the victimization risk were added to the model. The first, the inequality variable, indicated the proportion of income held by the richest 20 percent in relation to the poorest 20 percent in a specific geographic area. The geographic areas were Federation Units (states and the Federal District) as opposed to municipalities or neighborhoods because information for these smaller areas was not provided in all the surveys. The expected result is that the greater the proportion of the geographic area's total wealth held by the wealthiest 20 percent relative to the poorest 20 percent, the greater the risk of victimization. Although observed with other inequality proxies, this relationship was also found in other studies, notably those by Araujo and Fajnzylber (2001); Mendonça et al. (2003) and Scorzafave and Soares (2009).

The homicide variable was included because it was expected that the greater the number of homicides per capita in an area, the greater the risk of victimization since the area's residents would be exposed to more violence that those living in areas with fewer homicides per capita. The variable is defined by the homicide rate per 100,000 inhabitants in a Federation Unit and the expected relationship is positive. The gangs variable represents an individual's perception of the influence of gangs in the individual's neighborhood and was added to complement the scope of the homicide variable. The expected relationship is positive since this type of organization uses, for the most part, violence for the resolution of conflicts (McCarthy, 2013).

Year and state dummies variables were also included in the empirical model to control the effects of time and for the heterogeneity among Federation Units, both of which could influence the risk of victimization.

Finally, it should be pointed out that the variable of interest in this study, social capital, is potentially endogenous due to the possible simultaneity between this proxy variable and the risk of victimization. Therefore, we included two instrumental variables in the models, politics and news. The identification strategy is presented below.

When estimating the relation between risk of victimization and level of social capital there is a potential problem with endogeneity. This is because the relationship between social capital and crime reduction is not a one-way relationship; it is also possible to analyze the effect of crime on social capital.

Cuesta and Alda (2012) note that criminologists and sociologists have developed theories emphasizing that "victims trust less than non-victims;" in this way crime has reduced social capital. Among the scarce literature that seeks to analyze this relationship, we highlight Blanco's study (2013) of Mexico. Blanco (2013) employed an ordered logit model with fixed effects and found that insecurity and crime reduce confidence in democracy and institutions. There are also studies by Blanco and Ruiz (2013) corroborating this result for Colombia and 
The role of social capital in the victimization risk against property: evidence from Brazil

by Corbacho et al. (2014) that addresses the problem in Latin American countries by applying propensity score matching methodology. The main conclusion from these three studies is that crime negatively affects social capital.

Given the possibility of two-way causality between the variables of interest in our study, one or more instrumental variables with exogenous variation were added in a Two-Stage Least Squares estimation (TSLS). For details, see Greene (2012, pp. 259-273).

In the context of a binary result model, an IV-Probit model is fitted, which in the first stage consists of estimating the equation

$$
\text { social capital }_{i, t}=\pi_{0}+\sum_{t=1}^{k} \pi_{1} X_{i t}+\pi_{2} Z+\vartheta_{i}
$$

to obtain estimates for the potentially endogenous variable ( social capital $_{i, t}$ ) as a function of the explanatory variables in Eq. 7 with the addition of $\mathrm{Z}$ instruments. It is assumed that the instruments are not correlated with the Eq. 7 error term; however, they are correlated with the endogenous regressor. The random error term $\vartheta_{i}$ is independent and identically distributed. The predicted values of social capital in the reduced form of Eq. 11 replace the original variable contained in the model expressed in Eq. 7. After this substitution, Eq. 7 is estimated by maximum likelihood. The instruments should have two attributes: i) explanatory power over the endogenous variable; and ii) not be correlated with the dependent variable and, consequently, with the equation's error term. In our specific case, the instruments must have a relation with social capital, but not correlate with the dependent variable victim.

In order to meet these requirements, two variables were selected from the database and labeled "politics" and "news". Their validity as instruments was evaluated using the Hausman (1978) and Sargan (1958) tests.

The politics variable is a proxy representing an individual's degree of political engagement. Wollebaek and Selle (2003) consider this variable to be multidimensional and that it reflects on an individual's participation in protests, participation and interest in politics and political groups, and other related variables. In this study, we assign a value to the politics variable that is determined by the LAPOP survey respondent's answer to the question

\section{How much interest do you have in politics: a lot, some, little or none?}

The argument that the instrumental variable politics has explanatory power for a correlation between social capital and politics, thereby satisfying attribute i), is based on Putnam's (1995, p. 665-666) notion that social capital (social trust) is strongly correlated with political engagement in that interest in politics affects an individual's level of trust in political institutions. The relationship between social capital and political engagement tends to be negative (Wollebaek; Selle 2002, p. 39). In order to comply with attribute ii), there is no reason to assume there is a relationship between the degree of interest in politics and the risk of victimization. 
The inclusion of the second instrumental variable, news, allows one to determine if the instruments are valid using an overidentification test, which can only be conducted when two or more variables are used as instruments for an endogenous regressor. In the study's model, this variable indicates the frequency that the individual reads or listens to news, and the data that determines this variable's value come from answers to the Lapop survey question,

About how often do you pay attention to the news, whether on TV, the radio, newspapers or the internet?

It is expected that the frequency that the individual is exposed to news influences the individual's level of trust, satisfying attribute i), but the frequency that the individual is exposed to news does not influence the victimization risk, satisfying attribute ii). Therefore, as in the case of the first instrument, news is a variable with exogenous variation to victimization.

\section{Preliminary analysis}

Nearly 19 percent of individuals sampled in the 2010, 2012, and 2014 surveys (849 individuals) had suffered some crime against property in the 12 months prior to the interview. Table 2 shows the nature of the crime per year of the survey. The most frequently suffered crime against property was armed robbery (39.9\%), followed by unarmed robbery with no physical threats $(20.8 \%)$, then by home burglary (14.49\%). Emphasis can be placed on the percentage of respondents that suffered from home burglaries between 2010 and 2014, declining from 18 percent in 2010 to 9.9 percent in 2014. Unfortunately, the frequency of unarmed robberies with physical threat increased from 7.5 percent in 2010 to 13 percent in 2014.

Table 2

Type of crime suffered per year of survey

\begin{tabular}{|c|c|c|c|c|c|c|c|c|}
\hline \multirow{3}{*}{$\begin{array}{l}\text { Type of crime you have suffered in the last } \\
\qquad 12 \text { months }\end{array}$} & \multicolumn{6}{|c|}{ Year } & & \\
\hline & \multicolumn{2}{|c|}{2010} & \multicolumn{2}{|c|}{2012} & \multicolumn{2}{|c|}{2014} & \multicolumn{2}{|c|}{ Total } \\
\hline & $\mathrm{n}$ & $\%$ & $\mathrm{n}$ & $\%$ & $\mathrm{n}$ & $\%$ & $\mathrm{n}$ & $\%$ \\
\hline Armed robbery & 160 & 40.0 & 98 & 43.4 & 81 & 36.3 & 339 & 39.9 \\
\hline Unarmed robbery, no physical threats & 84 & 21.0 & 41 & 18.1 & 52 & 23.3 & 177 & 20.8 \\
\hline Burglary of your home & 72 & 18.0 & 29 & 12.8 & 22 & 9.9 & 123 & 14.5 \\
\hline Unarmed robbery with physical threats & 30 & 7.5 & 14 & 6.2 & 29 & 13.0 & 73 & 8.6 \\
\hline Extorsion & 17 & 4.2 & 13 & 5.7 & 13 & 5.8 & 43 & 5.0 \\
\hline Other & 37 & 9.3 & 31 & 13.7 & 26 & 5.8 & 94 & 5.0 \\
\hline Total & 400 & 100 & 226 & 100 & 223 & 100 & 849 & 100 \\
\hline
\end{tabular}

Source: Prepared by the authors.

Table 3 presents the joint frequency of the surveyed individuals' responses to questions regarding level of interpersonal trust and victimization. 
It is observed that in the sample only 20.4 percent of the surveyed Brazilians, both nonvictims and victims, consider people very trustworthy, 70.7 percent consider people to be somewhat trustworthy or not very trustworthy, and 8.8 percent consider people to be untrustworthy. It can be seen that victims have a low level of trust relative to non-victims, 15.8 percent vs. 21.2 percent, respectively, corroborating the not too shocking hypothesis that victims trust others less than non-victims (Cuesta; Alda, 2012).

Table 3

Interpersonal confidence levels for victims and non-victims of crime

\begin{tabular}{|c|c|c|c|c|c|c|c|c|c|c|}
\hline \multirow{3}{*}{$\begin{array}{l}\text { Have you been a } \\
\text { victim of any type } \\
\text { of crime in the } \\
\text { past } 12 \text { months? }\end{array}$} & \multicolumn{10}{|c|}{ Interpersonal confidence level } \\
\hline & \multicolumn{2}{|c|}{ Very trustworthy } & \multicolumn{2}{|c|}{$\begin{array}{l}\text { Somewhat } \\
\text { trustworthy }\end{array}$} & \multicolumn{2}{|c|}{$\begin{array}{c}\text { Not very } \\
\text { trustworthy }\end{array}$} & \multicolumn{2}{|c|}{ Untrustworhy } & \multicolumn{2}{|c|}{ Total } \\
\hline & $\mathrm{n}$ & $\%$ & $\mathrm{n}$ & $\%$ & $\mathrm{n}$ & $\%$ & $\mathrm{n}$ & $\%$ & $\mathrm{n}$ & $\%$ \\
\hline No & 939 & 21.2 & 1.704 & 38.5 & 1.418 & 32.0 & 366 & 8.3 & 4.427 & 100 \\
\hline Yes & 132 & 15.8 & 287 & 34.3 & 318 & 38.0 & 99 & 11.8 & 836 & 100 \\
\hline Total & 1,071 & 20.4 & 1,991 & 37.8 & 1,736 & 33.0 & 465 & 8.8 & 5,263 & 100 \\
\hline
\end{tabular}

Source: Prepared by the authors.

Table 4 shows the average values for the victims' and non-victims' characteristics. Corroborating results shown in Table 3, the first conclusion is that non-victims have a higher level of interpersonal confidence than victims. In addition, the characteristics that stood out most within the victims' group were the values for males, living in urban areas, between 16 and 25 years of age, having a higher educational level, living where there are gangs, and living in Federal Units with higher homicide rates.

The last column of Table 4 reports the results of the t-test of equality of means and the z-test of proportions (for the cases of subdivided variables) between the two groups that compose the sample: victims and non-victims.

Table 4

Unpaired $\mathrm{t}$ and $\mathrm{z}$ tests between victimized and non-victimized individuals

\begin{tabular}{l|c|c|c}
\hline \multirow{2}{*}{\begin{tabular}{l} 
Social capital \\
\multirow{3}{*}{ Work }
\end{tabular}} & Non-victimized & Victmized & z/t test \\
\cline { 2 - 4 } & 0.59 & 0.48 & $0.11^{* * *}$ \\
\hline \multirow{2}{*}{ Man } & $(0.49)$ & $(0.50)$ & $(0.02)$ \\
\cline { 2 - 4 } & 0.71 & 0.8 & $-0.08^{* * *}$ \\
\hline \multirow{2}{*}{ Urban } & $(0.45)$ & $(0.40)$ & $-0.02)$ \\
\hline \multirow{2}{*}{$\begin{array}{l}\text { Classpop }(<25 \text { thousand } \\
\text { inhab.) }\end{array}$} & 0.49 & 0.53 & $(0.02)$ \\
\hline & $(0.50)$ & $(0.50)$ & $-0.08^{* * *}$ \\
\cline { 2 - 4 } & 0.85 & 0.93 & $(0.01)$ \\
\cline { 2 - 4 } & $(0.36)$ & $(0.25)$ & $-0.09 * * *$ \\
\hline
\end{tabular}


Table 4 - Continuation

\begin{tabular}{|c|c|c|c|}
\hline & Non-victimized & Victmized & $\mathrm{z} / \mathrm{t}$ test \\
\hline \multirow{2}{*}{ Classpop $(\geq 25 k$ to $<50 k)$} & 0.20 & 0.24 & $-0.05 * * *$ \\
\hline & $(0.40)$ & $(0.43)$ & $(0.02)$ \\
\hline \multirow{2}{*}{ Classpop $(\geq 50 k$ to $<200 k)$} & 0.22 & 0.21 & 0.01 \\
\hline & $(0.42)$ & $(0.41)$ & $(0.02)$ \\
\hline \multirow{2}{*}{ Classpop $(\geq 200 k$ to $<500)$} & 0.25 & 0.15 & $0.09 * * *$ \\
\hline & $(0.43)$ & $(0.36)$ & $(0.02)$ \\
\hline \multirow{2}{*}{$\begin{array}{l}\text { Classpop ( } \geq 500 \text { thousand } \\
\text { inhab.) }\end{array}$} & 0.08 & 0.05 & $0.02 * * *$ \\
\hline & $(0.28)$ & $(0.23)$ & $(0.01)$ \\
\hline \multirow{2}{*}{ Age (16-25) } & 0.23 & 0.27 & $-0.04 * * *$ \\
\hline & $(0.42)$ & $(0.44)$ & $(0.02)$ \\
\hline \multirow{2}{*}{ Age (26-35) } & 0.25 & 0.26 & -0.01 \\
\hline & $(0.43)$ & $(0.44)$ & $(0.02)$ \\
\hline \multirow{2}{*}{ Age (36-45) } & 0.20 & 0.25 & $-0.04 * * *$ \\
\hline & $(0.40)$ & $(0.43)$ & $(0.02)$ \\
\hline \multirow{2}{*}{ Age (46+) } & 0.32 & 0.22 & $0.10 * * *$ \\
\hline & $(0.47)$ & $(0.41)$ & $(0.02)$ \\
\hline \multirow{2}{*}{ Schooling } & 8.25 & 9.26 & $-1.07 * * *$ \\
\hline & $(3.91)$ & $(3.75)$ & $(0.15)$ \\
\hline \multirow{2}{*}{ Income (class A) } & 0.29 & 0.29 & -0.00 \\
\hline & $(0.45)$ & $(0.45)$ & $(0.02)$ \\
\hline \multirow{2}{*}{ incOme (class B) } & 0.25 & 0.26 & -0.00 \\
\hline & $(0.44)$ & $(0.44)$ & $(0.02)$ \\
\hline \multirow{2}{*}{ Income (class C) } & 0.46 & 0.45 & 0.01 \\
\hline & $(0.50)$ & $(0.50)$ & $(0.02)$ \\
\hline \multirow{2}{*}{ Inequality } & 0.55 & 0.55 & 0.00 \\
\hline & $(0.14)$ & $(0.13)$ & $(0.01)$ \\
\hline \multirow{2}{*}{ Homicide } & 26.71 & 27.81 & $-0.97 * *$ \\
\hline & $(12.61)$ & $(12.88)$ & $(0.48)$ \\
\hline \multirow{2}{*}{ Gangs (nothing affected) } & 0.16 & 0.31 & $-0.15 * * *$ \\
\hline & $(0.00)$ & $(0.02)$ & $(0.02)$ \\
\hline \multirow{2}{*}{ Gangs (slightly affected) } & 0.16 & 0.18 & $-0.02 *$ \\
\hline & $(0.00)$ & $(0.01)$ & $(0.01)$ \\
\hline \multirow{2}{*}{ Gangs (reasonably affected) } & 0.36 & 0.31 & $0.04 * *$ \\
\hline & $(0.00)$ & $(0.01)$ & $(0.01)$ \\
\hline \multirow{2}{*}{ Gangs (greatly affected) } & 0.30 & 0.18 & $0.12 * * *$ \\
\hline & $(0,00)$ & $(0,01)$ & $(0,01)$ \\
\hline
\end{tabular}

Source: Prepared by the authors. Note: standard errors in parentheses; $* * *, * *$ and $*$ denote significance at the $1 \%, 5 \%$ and $10 \%$ level respectively.

\section{Results}

Table 5 shows the results from the three variations of the probit empirical model: the basic model without instrumental variables (Model 3) and two variations that include 
The role of social capital in the victimization risk against property: evidence from Brazil

instrumental variables (IV-Probit $1 \& 2$ ). Model I includes only the instrumental variable politics. Model II includes both politics and news, the other instrumental variable. The inclusion of the second instrument allows the application of an overidentification test. Model III does not include the instrumental variables, that is, without correction for potential endogeneity. Results from this model are shown in the last column of Table 3.

For Model I, the Wald test result indicates that the exogeneity hypothesis should be rejected. Therefore, endogeneity must be treated with the use of instrumental variables. With the inclusion of the politics variable as an instrument (Model I), the Hausman test indicated that the estimates are consistent

Model II includes instrumental variables politics and news. For Model II, the Sargan test indicated that the hypothesis of overidentification cannot be rejected (p-value 0.6958), implying orthogonality between the instruments and the error term. In other words, the Sargan test indicated that the instruments used are statistically valid.

Another fact corroborating the instruments' validity is that the variable politics was statistically significant in the first stage for Model I and both politics and news were significant for Model II, corroborating the fact that these instruments are correlated with the endogenous social capital regressor.

Interpreting the results, it can be seen that regardless of which adjusted model is used, there is a negative and statistically significant relationship between social capital and victimization risk. It should be noted that the model without correction for endogeneity (Model III) also presents this negative association, however, in a magnitude lower than that estimated by models I and II, which leads to the conclusion that omission of the instrumental variables for the treatment of endogeneity leads to the underestimation of social capital's effect on the risk of victimization.

Our results corroborate findings from international studies that also empirically investigated the relationship between social capital and the risk of victimization. Akçomak \& Weel (2012) found that social capital is able to explain about 10 percent of the changes in criminal rates in the Netherlands. Putnam (2001) found that the social capital ratio in the United States is negatively correlated with the county's homicide rate. Takagi et al. (2012) found that social capital significantly reduces the risk of victimization in the city of Tokyo. The same result was found for the city of Cali, Colombia by Cuesta \& Alda (2012). With a cross-country sample, Roh and Lee (2013) found that social capital reduced the risk of robbery. 
Table 5

Estimated coefficients in the first stage and marginal effects in the mean (M.E.) obtained in the estimation of IV-Probit and the Probit models

\begin{tabular}{|c|c|c|c|c|c|}
\hline & \multicolumn{2}{|c|}{ Model I (IV-Probit) } & \multicolumn{2}{|c|}{ Model II (IV-Probit) } & \multirow{2}{*}{$\begin{array}{c}\begin{array}{c}\text { Model III } \\
\text { (Probit) }\end{array} \\
\text { M.E. }\end{array}$} \\
\hline & First stage & M.E. & First stage & M.E. & \\
\hline Social capital & & $\begin{array}{c}-0.2736^{* *} \\
(0.1398) \\
\end{array}$ & & $\begin{array}{c}-0,2923 * * \\
(0,1444) \\
\end{array}$ & $\begin{array}{c}-0,0402 * * * \\
(0,0095)\end{array}$ \\
\hline Work & $\begin{array}{l}0.0316^{* * *} \\
(0.0158)\end{array}$ & $\begin{array}{c}0.0396 * * * \\
(0.0113)\end{array}$ & $\begin{array}{l}0.0302^{*} \\
(0.0159)\end{array}$ & $\begin{array}{c}0,0387 * * * \\
(0,0113)\end{array}$ & $\begin{array}{r}0,0311^{* *} \\
(0,0116)\end{array}$ \\
\hline Man & $\begin{array}{l}-0.0121 \\
(0.0137) \\
\end{array}$ & $\begin{array}{c}0.0110 \\
(0.0100)\end{array}$ & $\begin{array}{l}-0.0125 \\
(0.0134) \\
\end{array}$ & $\begin{array}{c}0,0103 \\
(0,0099) \\
\end{array}$ & $\begin{array}{l}0,0175^{*} \\
(0,0098)\end{array}$ \\
\hline Urban & $\begin{array}{l}0.0983 * * \\
(0.0371)\end{array}$ & $\begin{array}{c}0.1311 * * * \\
(0.0258)\end{array}$ & $\begin{array}{l}0.0960 * * \\
(0.0370)\end{array}$ & $\begin{array}{c}0,1309 * * * \\
(0,0262)\end{array}$ & $\begin{array}{c}0,1060 * * * \\
(0,0209)\end{array}$ \\
\hline $\begin{array}{l}\text { Classpop }(<25 \text { thous. } \\
\text { inhab.) }\end{array}$ & $\begin{array}{c}0.0339 \\
(0.0495)\end{array}$ & $\begin{array}{l}-0.0354 \\
(0.0492)\end{array}$ & $\begin{array}{c}0.0365 \\
(0.0489)\end{array}$ & $\begin{array}{l}-0,0319 \\
(0,0495)\end{array}$ & $\begin{array}{l}-0,0517 \\
(0,0464) \\
\end{array}$ \\
\hline Classpop $(\geq 25 k$ and $<50 k)$ & $\begin{array}{c}0.0282 \\
(0.0465) \\
\end{array}$ & $\begin{array}{l}-0.0258 \\
(0.0535)\end{array}$ & $\begin{array}{c}0.0312 \\
(0.0464) \\
\end{array}$ & $\begin{array}{l}-0,0241 \\
(0,0535)\end{array}$ & $\begin{array}{l}-0,0409 \\
(0,0506)\end{array}$ \\
\hline Classpop ( $\geq 50 k$ and $<200 k$ ) & $\begin{array}{l}-0.0574 \\
(0.0419)\end{array}$ & $\begin{array}{c}-0.0804 * * \\
(0.0394) \\
\end{array}$ & $\begin{array}{l}-0.0560 \\
(0.0418) \\
\end{array}$ & $\begin{array}{c}-0,0795 * * \\
(0,0392)\end{array}$ & $\begin{array}{l}-0,0689 * \\
(0,0367) \\
\end{array}$ \\
\hline $\begin{array}{l}\text { Classpop }(\geq 200 k \text { and } \\
<500 k)\end{array}$ & $\begin{array}{c}-0.0744 * * \\
(0.0381) \\
\end{array}$ & $\begin{array}{c}-0.1109^{* *} \\
(0.0417)\end{array}$ & $\begin{array}{l}-0.0729 * \\
(0.0382)\end{array}$ & $\begin{array}{c}-0,1106^{* *} \\
(0,0412)\end{array}$ & $\begin{array}{c}-0,0965^{* *} \\
(0,0430)\end{array}$ \\
\hline Age (16-25) & $\begin{array}{c}0.1185^{* * * *} \\
(0.0243)\end{array}$ & $\begin{array}{c}0.0417 * * * \\
(0.0186)\end{array}$ & $\begin{array}{c}0.1184 * * * \\
(0.0249)\end{array}$ & $\begin{array}{c}0,0740^{* * * *} \\
(0,0188)\end{array}$ & $\begin{array}{c}0,0346 * * \\
(0,0135)\end{array}$ \\
\hline Age (26-35) & $\begin{array}{c}0.0777 * * * * \\
(0.0170)\end{array}$ & $\begin{array}{l}0.0403 * * \\
(0.0168)\end{array}$ & $\begin{array}{c}0.0770 * * * \\
(0.0171)\end{array}$ & $\begin{array}{l}0,0431^{* * *} \\
(0,0166)\end{array}$ & $\begin{array}{c}0,0170 \\
(0,0132) \\
\end{array}$ \\
\hline Age (36-45) & $\begin{array}{l}0.0477 * * \\
(0.0190)\end{array}$ & $\begin{array}{c}0.0589 * * * \\
(0.0139) \\
\end{array}$ & $\begin{array}{l}0.0478^{* * *} \\
(0.0191)\end{array}$ & $\begin{array}{c}0,0600^{* * * *} \\
(0,0140)\end{array}$ & $\begin{array}{c}0,0486^{* * *} * \\
(0,0135)\end{array}$ \\
\hline Schooling & $\begin{array}{c}-0.0018 \\
(0.0024) \\
\end{array}$ & $\begin{array}{c}0.0043 * * \\
(0.0016)\end{array}$ & $\begin{array}{c}-0.0016 \\
(0.0024) \\
\end{array}$ & $\begin{array}{c}0,0042 * * \\
(0,0017)\end{array}$ & $\begin{array}{c}0,0057^{* * * *} \\
(0,0015)\end{array}$ \\
\hline Income (class B) & $\begin{array}{c}0.0573 * * \\
(0.0166) \\
\end{array}$ & $\begin{array}{l}0.0274 * \\
(0.0158) \\
\end{array}$ & $\begin{array}{c}0.0581 * * \\
(0.0167)\end{array}$ & $\begin{array}{l}0,0292 * \\
(0,0164)\end{array}$ & $\begin{array}{c}0,0101 \\
(0,0141)\end{array}$ \\
\hline Income (class $C$ ) & $\begin{array}{c}0.0637 * * \\
(0.0271)\end{array}$ & $\begin{array}{c}0.0342 \\
(0.0271)\end{array}$ & $\begin{array}{c}0.0620 * * \\
(0.0267)\end{array}$ & $\begin{array}{c}0,0363 \\
(0,0278)\end{array}$ & $\begin{array}{c}0,0129 \\
(0,0209)\end{array}$ \\
\hline Inequality & $\begin{array}{c}0.4845 \\
(0.5068) \\
\end{array}$ & $\begin{array}{l}-0.5865 \\
(0.3978) \\
\end{array}$ & $\begin{array}{c}0.4842 \\
(0.5001)\end{array}$ & $\begin{array}{l}-0,5689 \\
(0,3904)\end{array}$ & $\begin{array}{c}-0,7960 * * \\
(0,3826)\end{array}$ \\
\hline Homicide & $\begin{array}{c}0.0028 \\
(0.0017)\end{array}$ & $\begin{array}{c}0.0022 \\
(0.0015)\end{array}$ & $\begin{array}{c}0.0027 \\
(0.0017)\end{array}$ & $\begin{array}{c}0,0023 \\
(0,0014)\end{array}$ & $\begin{array}{c}0,0015 \\
(0,0014)\end{array}$ \\
\hline Gangs (slightly affected) & $\begin{array}{c}-0.1656 * * * \\
(0.0287) \\
\end{array}$ & $\begin{array}{c}-0.1138^{* * * *} \\
(0.0260) \\
\end{array}$ & $\begin{array}{c}-0.1635^{* * * *} \\
(0.0281)\end{array}$ & $\begin{array}{c}-0,1139 * * * \\
(0,0248) \\
\end{array}$ & $\begin{array}{c}-0,0617 * * * \\
(0,0178) \\
\end{array}$ \\
\hline Gangs (reasonably affected) & $\begin{array}{c}-0.1474 * * * \\
(0.0216)\end{array}$ & $\begin{array}{c}-0.1420 * * * \\
(0.0185)\end{array}$ & $\begin{array}{c}-0.1481 * * * \\
(0.0216)\end{array}$ & $\begin{array}{c}-0,1439 * * * \\
(0,0176)\end{array}$ & $\begin{array}{c}-0,0979 * * * \\
(0,0157)\end{array}$ \\
\hline Gangs (greatly affected) & $\begin{array}{c}-0.1925 * * * \\
(0.0219)\end{array}$ & $\begin{array}{c}-0.1789 \text { *** } \\
(0.0212)\end{array}$ & $\begin{array}{c}-0.1940 * * * \\
(0.0219)\end{array}$ & $\begin{array}{c}-0,1806 * * * \\
(0,0202)\end{array}$ & $\begin{array}{c}-0,1238^{* * * *} \\
(0,0175)\end{array}$ \\
\hline Politics & $\begin{array}{c}-0.0338 * * * \\
(0.0089)\end{array}$ & & $\begin{array}{c}-0.0315^{* *} \\
(0.0096)\end{array}$ & & \\
\hline News & & & $\begin{array}{l}0.0098^{*} \\
(0.0057) \\
\end{array}$ & & \\
\hline Dummies for year and state & \multicolumn{2}{|c|}{ Yes } & \multicolumn{2}{|c|}{ Yes } & Yes \\
\hline Hausman $(p$-value $)$ & \multicolumn{2}{|c|}{0.9993} & \multirow{2}{*}{\multicolumn{2}{|c|}{0.0361}} & \\
\hline Wald (p-value) & \multicolumn{2}{|c|}{0.0359} & & & \\
\hline Sargan (p-value) & & & \multicolumn{2}{|c|}{0.6958} & \\
\hline $\mathrm{N}$ & \multicolumn{2}{|c|}{4.905} & \multicolumn{2}{|c|}{4.875} & 4.936 \\
\hline
\end{tabular}

Note: standard errors in parentheses; $* * *, * *$ and $*$ denote significance at $1 \%, 5 \%$ and $10 \%$ levels, respectively; Estimated probability coefficients are available upon request. 
The empirical results presented in Table 5 for the relationship between social capital and the risk of victimization align with those predicted in Section 2's discussion of the theoretical model. For the LLM theoretical model, higher confidence levels imply a reduction in the net benefit of a criminal practice, that is, the moral threshold for committing a criminal act rises. In the CKL theoretical approach, higher confidence levels can be verified only in regions where the victimization risk is low. In addition, an increase in a particular society's level of social capital would imply an increase in the likelihood that its citizens' cooperate for their mutual benefit, such as by actively combating crime, thereby reducing their risk of victimization (Putnam, 1993; Dilulio, 1996).

The level of social cohesiveness generated by interpersonal trust is a factor that affects the risk of victimization. It has been found that a sense of societal unity will positively influence a society's motivation to report crimes to competent authorities, thereby, increasing the potential cost of committing a crime (Conklin, 1975; Black, 1976; Gottfredson; Hindelang, 1979; Baumer 2002; Warner, 2007). These authors put forward the following hypothesis: if individuals living in the same neighborhood trust each other, they will report the crime to the police and will trust the police to both investigate the crime and not initiate reprisals for reporting the crime. If the crime is reported to trustworthy, competent authorities, the risk of victimization is reduced as the threat of police investigation will inhibit criminal activity.

Independent of the analyzed model, data showed that there is a negative relation between risk of victimization and age. The risk is greater for individuals between 16 and 25 years of age than for those aged 46 and over. This is unsurprising since younger individuals tend to be exposed in environments that have a higher risk of victimization. This age relationship was also verified in Madalozzo and Furtado (2011) for robbery, auto theft, and physical aggression. The same relationship between age and both robberies and home burglaries was found by Justus and Kassouf (2013).

An estimated positive relation between the variables victim and work was established by all variations of our study's model, suggesting that individuals who study and/or work are at greater risk of suffering a crime than those that do not. Assuming that most students and workers carry out these activities outside the home, this finding is most probably due to greater exposure to public spaces, such as more time spent traveling or eating outside the home. The result is in line with the CKL theory, which relates greater exposure with an increase in the risk of victimization. A study by Beato et al. (2004) also found the same relationship.

Although we expected a positive relation between the risk of victimization and the variable man, results indicated that the relationship was not significant. However, this unexpected finding agreed with results from a study conducted by Justus and Kassouf (2013) using data from a sample of people living in the municipality of São Paulo.

The fact that the individual resides in the urban environment appeared to be positively related to the risk of victimization. In the urban environment, there is a greater agglomeration of individuals belonging to different social classes, which leads to an extremely dynamic set of 
economic and social relations that favors the occurrence of crime. This result is theoretically supported by the CKL theory. It should be noted that the urban variable together with the categorical classpop was used to control the distance between individuals $(d)$, as established in the LLM theoretical model and specified in Eq. 3.

For the income variable, Gavíria and Pagés (2002) suggest that individuals' incomes determine both their attractiveness to criminals and their ability to contract security services to protect their residences and themselves and minimize exposure in unsafe public spaces. The attributes of the wealthy, attractiveness and protected aloofness, have opposing effects on the rational criminal when considering the commission of an illegal act. On the one hand, the wealthy are more likely to attract the criminal's eye but on the other, the wealthy are more likely to employ protective measures. The much less wealthy are less likely to attract criminals but do not have enough resources to acquire protective services or devices. In our study, income level showed a negative relation with the risk of victimization (the estimated coefficients of $\mathrm{B}$ and $\mathrm{C}$ income classes were higher than for those at the highest income level).

Finally, the variable gangs, which acted as a proxy for a neighborhood's intrinsic security characteristics, presented a negative estimated coefficient. In other words, the perception that there is the presence of gangs in a neighborhood reduces the risk of victimization. A priori, we expected the opposite: more gangs lead to greater victimization. Possibly, gangs protect the neighborhood and resolve civil conflicts, play the role of the competent authorities, and/or discourage appearances in public, thereby, reducing victimization. This hypothesis should be investigated in future studies.

\section{Concluding remarks}

Crime is a complex phenomenon, and the study of its causes requires a multidisciplinary analysis. Both the "supply" side of crime, that is, what influences the individual's decision to engage in illegal activity, as well as the "demand" side, or what conditions influence the possibility of victimization, must be investigated to understand the phenomenon of crime and victimization.

In this study, we tested the hypothesis that social capital has a negative effect on the risk of victimization against property and, consequently, crime rates. We found this hypothesis to be valid. The causal effect of social capital on the risk of victimization travels through two main channels.

The first channel is related to the fact that a higher level of social capital among individuals of the same community strengthens social connections, which encourages the adoption of mechanisms capable of generating mutual social benefit, such as the reciprocal protection among neighbors and the adoption of security devices common to neighborhoods. The second channel is related to the "supply" of crimes. In communities where social capital is high, that is, where people trust each other, it is to be expected that the moral threshold that must be crossed before the commission of a crime is higher; therefore, individuals are less 
The role of social capital in the victimization risk against property: evidence from Brazil

willing to commit crimes. This connection is supported by the theory of social disorganization, in which social aspects related to an individual's experience in the community influence the decision to commit crimes or take part in licit activities.

We highlight that the results related to the variable of interest - social capital - were robust when the basic model was adjusted to control for endogeneity. We conclude that the treatment applied to control endogeneity was sufficient. We found that uncorrected estimates for endogeneity underestimated the effect of social capital on the risk of victimization.

Since a higher level of social capital can reduce the risk of victimization, and consequently reduce the level of crime, public policies that increase social capital would be useful tools if reducing a country's crime level is a priority. But increasing the level of social capital can be a complex and multi-factored endeavor since it entails raising the society's level of trust in others and in institutions and in raising the population's moral threshold. The state could and should take steps to increase social capital by actively promoting greater societal engagement, improving its image as an institution meriting confidence, showing that it is capable of securing its citizens' personal security, and demonstrating that it is actively engaged in the struggle to improve their lives.

The Programa Desarollo, Seguridad y Paz (Desepaz) implemented in Cali, Colombia, successfully raised the level of social capital within the city's districts by many means, among them it promoted and held community meetings between concerned citizens and the city's mayor regarding security issues. By the second year after the program's inauguration, homicide levels within the city had begun to fall, and this was after years of increasing rates. Besides holding weekly meetings between government officials and city residents, the program initiated the construction of legal institutions in neighborhoods farthest from the central region, widely disseminated relevant civic information, fostered positive social interactions, and actively promoted harmonious coexistence through peaceful communication during times of stress rather than physical altercations, such as those brought about by "road rage" during the rush hour. The program's successes indicate that by showing an interest it its residents' security and actively promoting their interests, the government can work to increase social capital.

\section{References}

AKÇOMAK, I. S.; WEEL, B. T. The impact of social capital on crime: evidence from the Netherlands. Regional Science and Urban Economics, v. 42, n. 1, p. 323-340, 2012.

ARAUJO JR. A.; FAJNZYLBER, P. O que causa a criminalidade violenta no Brasil? Uma análise a partir do modelo econômico do crime: 1981 a 1996. Cedeplar/Face/UFMG, 2001. (Texto para Discussão, n. 162).

BAUMER, E. P. Neighborhood disadvantage and police notification by victims of violence. Criminology, v. 40, n. 1, p. 579-617, 2002. 
Gustavo Carvalho Moreira, Ana Lucia Kassouf, Marcelo Justus

BEATO, F.; PEIXOTO, B. T.; VIEGAS, M. A. Crime, oportunidade e vitimização. Revista Brasileira de Ciências Sociais, v. 19, n. 55, p. 73-89, 2004.

BECKER, G. S. Crime and punishment: an economic approach. Journal of Political Economy, v. 76, n. 2, p. 169-217, 1968.

BERGH, A.; BJØRNSKOV, C. Trust, welfare states and income equality: sorting out the causality. European Journal of Political Economy, v. 35, n. 9, p. 183-199, 2014.

BEUGELSDIJK, S. A note on the theory and measurement of trust in explaining differences in economic growth. Cambridge Journal of Economics, v. 30, n. 5, p. 371-387, 2006.

BLACK, D. J. The behaviour of law. New York: Academic Press, 1976.

BLANCO, L. R. The impact of crime on trust in institutions in Mexico. European Journal of Political Economy, v. 32, n. 12, p. 38-55, 2013.

BLANCO, L. R.; RUIZ, I. The impact of crime and insecurity on trust in democracy and institutions. American Economic Review: Papers \& Proceedings, v. 103, n. 3, p. 284-288, 2013.

BURSIK, R. J.; GRASMICK, H. G. Neighborhoods and crime: the dimensions of effective community control. Lexington Books, 1993. 240p.

CAMERON, A. C.; MILLER, D. L. A practitioner's guide to cluster-robust inference. Journal of Human Resources, v. 50, n. 2, p. 317-372, 2015.

CAMERON, A. C.; TRIVEDI, P. K. Microeconometrics: methods and applications. Cambridge University Press, 2005.

COHEN, L. E.; KLUEGEL, J. R.; LAND, K. C. Social inequality and predatory criminal victimization: an exposition and test of a formal theory. American Sociologial Review, v. 46, n. 5, p. 505-524, 1981.

CONKLIN, J. E. The impact of crime. New York: Macmillan, 1975. (Discussion Paper).

CORBACHO, A.; PHILIPP, J.; RUIZ-VEGA, M. Crime and erosion of trust: evidence for Latin America. World Development, v. 70, n. 6, p. 400-415, 2014.

CUESTA, J.; ALDA, E.; LAMAS, J. Social capital, violence and public intervention: the case of Cali. Inter-American Development Bank, 2007.

CUESTA, J.; ALDA, E. The effects of trust on victimization in Colombia. Journal of Peace Research, v. 49, n. 6, p. 833-846, 2012.

DEARMON, J.; GRIER, K. Trust and development. Journal of Economic Behavior \& Organization, v. 71, p. 210-220, 2009.

DEARMON, J.; Grier, R. Trust and the accumulation of physical and human capital. European Journal of Political Economy, v. 27, p. 507-519, 2011. 
The role of social capital in the victimization risk against property: evidence from Brazil

DILULIO, J. Help wanted: economists, crime and public policy. Journal of Economic Perspectives, v. 10, n. 1, p. 3-24, 1996.

FUKUYAMA, F. Social capital and civil society. The Institute of Public Policy. George Mason University, 1999.

GAVÍRIA, A.; PAGÉS, C. Patterns of crime victimization in Latin American cities. Journal of Development Economics, v. 67, n. 1, p. 181-203, 2002.

GOMES, F. A. R.; PAZ, L. S. The determinants of criminal victimization in São Paulo State, Brasil. Brazilian Review of Econometrics, v. 28, n. 2, p. 217-238, 2008.

GOTTFREDSON, M. R.; HINDELANG, M. J. A study of the behavior of law. American Sociological Review, v. 44, n. 1, p. 3-18, 1979.

HAUSMAN, J. A. Specification tests in econometrics. Econometrica, v. 46, n. 6, p. 1251$1271,1978$.

JACOBS, J. The life and death of great American cities. Random House, 1961.

JUSTUS, M.; KASSOUF, A. L. Existe explicação econômica para o sub-registro de crimes contra a propriedade? Revista de Economia Aplicada, v. 12, n. 1, p. 5-27, 2008.

JUSTUS, M.; KASSOUF, A. L. Evidence of the effect of wealth observed by criminals on the risk of becoming a victim of property crimes. Economia, Brasília, v. 14, p. 1-14, 2013.

JUSTUS, M.; SCORZAFAVE, L. G.; SANT'ANNA, E. G. Crime and victimization in rural Brazil. In: DONNERMEYER, Joseph F. (Org.). International Handbook of Rural Criminology. Routledge: Taylor \& Francis, 2016.

KNACK, S.; KEEFER, P. Does social capital have an economic pay-off? A cross country investigation. Quarterly Journal of Economics, v. 112, p. 1251-1288, 1997.

KNACK, S.; ZAK, P.J. Building trust: public policy, interpersonal trust, and economic development. Supreme Court Economic Review, v. 10, p. 91-107, 2002.

LAPOP. Latin American Public Opinion Project Survey: 2010-2014. Vanderbilt University. Disponível em: http://www.vanderbilt.edu/lapop. Acesso em: Oct. 2015.

LEDERMAN, D.; LOAYZA, N.; MENENDEZ, A. M. Violent crime: does social capital matter? Economic Development and Cultural Change, v. 50, n. 3, p. 509-539, 2002.

MADALOZZO, R.; FURTADO, G. M. Um estudo sobre vitimização para a cidade de São Paulo. Revista de Economia Política, v. 31, n. 1, p. 160-180, 2011.

McCARTHY, D. M. P. An economic history of organized crime: a national and transnational approach. Routledge, 2013. 336p.

MENDONÇA, J. C. M.; LOUREIRO, P. R. A.; SACHSIDA, A. Criminalidade e desigualdade social no Brasil. Rio de Janeiro: Ipea, 2003. (Texto para Discussão, n. 967). 
Gustavo Carvalho Moreira, Ana Lucia Kassouf, Marcelo Justus

MUHAMMAD, B. Rural crime and rural policing practices (Multicultural law enforcement). Detroit Police Department, 2002.

NORRIS, P. Does television erode social capital? A reply to Putnam. Political Science and Politics, v. 29, n. 3, p. 474-482, 1996.

PAPAGAPITOS, A.; RILEY, R. Social trust and human capital formation. Economics Letters, v. 102, n. 3, p. 158-160, 2009.

PEIXOTO, B.; SOUZA, L. G.; LIMA, R. S. Uma análise sistêmica: vitimização e políticas de segurança em São Paulo. Revista do Serviço Público, v. 63, n. 2, p. 217-236, 2012.

PUTNAM, R. Making democracy work: civic traditions in modern Italy. Princeton University Press, 1993.

PUTNAM, R. D. Bowling alone: the collapse and revival of American community. Simon \& Schuster, 2001. 544p.

QUDDUS, M.; GOLDSBY, M.; FAROOQUE, M. Trust: the social virtues and the creation of prosperity - a review article. Eastern Economic Journal, v. 26, n. 1, 2000.

RAND, M.; CATALANO, S. Criminal victimization, 2006. Bureau of Justice Statistics Bulletin, Dec. 2007.

ROH, S.; LEE, J. Social capital and crime: a cross-national multilevel study. International Journal of Law, Crime and Justice, v. 41, n. 1, p. 58-80, 2013.

SARGAN, J. D.; The estimation of economic relationships using instrumental variables. Econometrica, v. 26, n.1, p. 293-415, 1958.

SCORZAFAVE, L. G.; JUSTUS, M.; KASSOUF, A. L. Determinantes da vitimização e do sub-registro de crimes na cidade de São Paulo. CPP-Insper, 2011. 47p. (Relatório de Pesquisa).

SCORZAFAVE, L. G.; JUSTUS, M.; SHIKIDA, P. F. A. Safety in the global south: criminal victimization in Brazilian rural areas. Journal of Rural Studies, v. 39, n. 1, p. 247-261, 2015.

SCORZAFAVE, L. G.; SOARES, M. K. Income inequality and pecuniary crime. Economics Letters, v. 104, n. 1, p. 40-42, 2009.

SEIGEL, L. Journal of Criminology, $10^{\text {th }}$ ed. University of Massachusetts. Thomson Wadsworth, 2006.

TAKAGI, D.; IKEDA, K.; KAWACHI, I. Neighborhood social capital and crime victimization: comparison of spatial regression analysis and hierarchical regression analysis. Social Science \& Medicine, v. 75, n. 10, p. 1895-1902, 2012.

USLANER, E. M. The moral foundations of trust. Cambridge University Press, 2002. 316p. 
The role of social capital in the victimization risk against property: evidence from Brazil

WARNER, B. Directly intervence or call the authorities? A study of forms of neighborhood social control within a social disorganization framework. Criminology, v. 45, n. 1, p. 99-129, 2007.

WISHEIT, R. A.; FALCONE, D. N.; WELLS, L. E. Rural crime and rural policing. National Institute of Justice. Research in Action, 1994.

WORLD HEALTH ORGANIZATION - WHO. Global Status Report on Violence Prevention. 2014. 292p.

ZAK, P. J.; KNACK, S. Trust and growth. The Economic Journal, v. 111, n. 4, p. 295-321, 2001. 